Portland State University

PDXScholar

\title{
The Influence of Guilt Cognitions on Taxpayers' Voluntary Disclosures
}

\author{
Jonathan Farrar \\ Ryerson University \\ Cass Hausserman \\ Portland State University \\ Paul Dunn \\ Brock University
}

Follow this and additional works at: https://pdxscholar.library.pdx.edu/busadmin_fac

Part of the Accounting Commons, and the Business Administration, Management, and Operations Commons

Let us know how access to this document benefits you.

\section{Citation Details}

Farrar, Jonathan; Hausserman, Cass; and Dunn, Paul, "The Influence of Guilt Cognitions on Taxpayers' Voluntary Disclosures" (2016). Business Faculty Publications and Presentations. 39.

https://pdxscholar.library.pdx.edu/busadmin_fac/39

This Post-Print is brought to you for free and open access. It has been accepted for inclusion in Business Faculty Publications and Presentations by an authorized administrator of PDXScholar. Please contact us if we can make this document more accessible: pdxscholar@pdx.edu. 
The influence of guilt cognitions on taxpayers' amnesty disclosures

\author{
Jonathan Farrar \\ Assistant Professor \\ Ted Rogers School of Management \\ Ryerson University \\ Toronto, ON \\ e-mail: jmfarrar@ryerson.ca \\ Cass Hausserman * \\ Assistant Professor \\ School of Business Administration \\ Portland State University \\ Portland, OR \\ e-mail: cass.hausserman@pdx.edu
}

Paul Dunn

Associate Professor

Goodman School of Business

Brock University

St. Catharines, ON

e-mail:pdunn@brocku.ca

DRAFT: November 25, 2014

* Corresponding author

Acknowledgment.

This projected was funded by the Centre for Accounting Ethics, University of Waterloo. 


\title{
The influence of guilt cognitions on taxpayers' voluntary disclosures
}

\begin{abstract}
Guilt is a powerful emotion that is known to influence ethical decision-making. Nevertheless, the role of guilt cognitions in influencing restorative behaviour following an unethical action is not well understood. Guilt cognitions are interrelated beliefs about an individual's role in a negative event. We experimentally investigate the joint impact of three guilt cognitions - responsibility for a decision, justification for a decision, and foreseeability of consequences - on a taxpayer's decision to make a tax amnesty disclosure. Tax amnesties encourage delinquent taxpayers to self-correct to avoid severe penalties that would result if their tax evasion were discovered. Our findings suggest a three-way interaction effect such that taxpayers are likely to make tax amnesty disclosures when they foresee that they will be caught by the tax authority, unless they can diffuse responsibility for their evasion and justify their evasion. Implications for tax policy and tax professionals are discussed.
\end{abstract}

Keywords: guilt, guilt cognitions, tax amnesty, tax evasion, tax compliance 


\section{The influence of guilt cognitions on taxpayers' amnesty disclosures}

\section{Introduction}

The worldwide cost of taxpayer non-compliance is staggering. For example, the estimated 'tax gap' due to underreported taxable income is $\$ 450$ billion in the United States (Internal Revenue Service 2011) and \$80 billion in Canada (Canadians for Tax Fairness 2014). Thus, there is considerable interest and practical importance associated with knowing how to encourage taxpayers' voluntary compliance.

Tax compliance research tends to examine factors that can increase tax adherence and prevent tax evasion. Tax compliance consists of correctly reporting all items of income and deductions as mandated by law, whereas tax evasion is the intentional disregard of tax laws (Slemrod 2007). Typically, sanctions and penalties are used to prevent tax evasion, and while effective, this deterrence approach is very costly, resulting in significant reliance on voluntary reporting. Consequently, tax authorities are interested in cost-effective procedures to improve compliance. Tax amnesties, which are synonymous with voluntary disclosure programs, are relatively low-cost compliance initiatives in which taxpayers are given the opportunity to selfcorrect errors on previously filed tax returns. By self-correcting, taxpayers pay the taxes that would have resulted had the amounts been correctly reported, but often avoid the penalties and/or sanctions that would have been imposed if the tax authority had discovered the errors.

Tax authorities are increasingly turning to tax amnesties as a way to increase tax revenues. For example, in 2013, the Canada Revenue Agency processed 15,133 cases under its Voluntary Disclosure Program (a tax amnesty initiative), and recovered more than $\$ 1.2$ billion in unreported income at an administrative cost of just \$6.6 million (Canada 2013). Since 2000, 
more than half of the U.S. states have offered tax amnesty programs one or more times (Weinreb 2009). In the past fifty years, many developed countries (e.g., Greece, Ireland, Italy, Portugal, and Spain) and developing countries (e.g., Argentina, Brazil, Colombia, India, Philippines, and Turkey) have offered tax amnesties in response to economic problems such as recessions or public debt (Baer and Le Borgne 2008).

Although tax amnesties are effective at 'flushing out' tax evaders, much remains to be learned about the phenomenon of self-correcting in the tax context. Despite evidence that tax amnesties are moderately effective tax revenue collection strategies (Alm et al. 1990; Alm and Beck 1993; Christian et al. 2002; Fisher et al. 1989; Luna et al. 2006; Torgler and Schaltegger 2005), prior literature has not explicitly considered the underlying impetus for an individual's decision to make a tax amnesty disclosure. A better understanding of taxpayers' motivations in amnesty situations has the potential to inform and improve amnesty policy, regardless of legal context.

Guilt is a moral emotion (Tangney et al. 2007) that we expect will have a powerful impact on tax amnesty decisions, since guilt is known to influence both ethical decision-making (Steenhaut and Van Kenhove, 2006) and reparative behaviour (Ghorbani et al. 2013; Ilies et al. 2013). Accordingly, the purpose of this paper is to investigate the role of guilt in motivating an individual's tax amnesty decision.

Guilt is an agitation-based emotion of regretting a wrong decision or action (Ferguson and Stegge 1998). Guilt occurs in response to a moral transgression (Smith et al. 2002). When people feel guilty, they perceive their actions as wrong, assume responsibility for their decisions, and desire to find ways to either undo the wrongs or punish themselves (Eisenberg 2000). In a 
tax setting, this suggests that an individual who evaded taxes, and felt guilty about doing so, may be motivated to make a voluntary disclosure of their error as a means of assuming responsibility and atoning for the transgression. ${ }^{1}$

We used an experimental approach to investigate how guilt influences a taxpayer's decision to make a tax amnesty disclosure. An experiment is able to manipulate the relevant factors of interest while controlling for other factors that are outside of the scope of the study. Kubany and Watson (2003) developed a multidimensional model of guilt cognitions. Guilt cognitions are interrelated beliefs about an individual's role in a negative event. We conducted an experiment on 239 Canadian taxpayers to examine how three guilt cognitions - responsibility for a decision, justification for a decision, and foreseeability of consequences - jointly influence tax amnesty decisions.

Participants were given a scenario in which a taxpayer, who was given an inheritance, transferred the proceeds to a bank account in the Cayman Islands, unbeknownst to the tax authority. The taxpayer never reported any of her subsequent investment income on her tax return. After manipulating responsibility, justification, and foreseeability, we asked participants whether they thought that the taxpayer would make a tax amnesty disclosure. Our results show an interactive effect of the three guilt cognitions, such that taxpayers are more likely to make tax amnesty disclosures once they foresee that they will be caught, unless they can justify their tax evasions and diffuse responsibility for their behaviour by blaming tax advisors.

\footnotetext{
${ }^{1}$ Guilt and shame are the two emotions most relevant to ethical decision-making (Tangney et al., 2007). Shame is a dejection-based emotion arising from public exposure (Ferguson and Stegge 1998), and is not relevant to the tax amnesty decision, since a taxpayer who makes an amnesty disclosure is known only to a tax authority, and would not be publicly exposed.
} 
Our results suggest practical implications for tax authorities, as well as tax and other financial professionals. Appealing to taxpayers' guilt through efforts to increase the foreseeability of the possible negative consequences of tax evasion may be a promising strategy in encouraging non-compliers to self-correct. Tax and other financial professionals could emphasize legal and ethical reporting options to their noncompliant clients, which should result in a greater likelihood of them making a tax amnesty disclosure. Also, since our results suggest that taxpayers can diffuse personal responsibility for unethical reporting just by hearing an unethical inference from a tax advisor, tax advisors should be prudent when discussing tax reporting options.

Several contributions emerge from our study. First, we find causal evidence that appeals to guilt are effective in increasing the likelihood that taxpayers will make tax amnesty disclosures. We therefore contribute to the tax compliance literature by demonstrating the importance of guilt in encouraging tax compliance. Prior guilt research has conceptualized guilt rather broadly, without considering the nuances of this construct. Therefore, our second contribution is that we provide empirical support for Kubany and Watson's (2003) multidimensional model of guilt by showing that responsibility, justification, and foreseeability interact to influence restorative behaviour. Thirdly, we contribute to the restorative justice literature by finding that voluntary disclosures, which are a form of restorative behaviour (Wenzel et al. 2008), are directly influenced by appeals to guilt.

The remainder of the paper is organized as follows. In the next section, we formulate our hypothesis. Section three describes our experiment, and section four reports our results. We 
conclude with a discussion of the implications of our findings for tax policy makers, tax or other financial professionals, and tax ethics researchers.

\section{Hypothesis Development}

Tax researchers have generally found a positive association between tax amnesty programs and subsequent compliance (Alm et al. 1990; Alm and Beck 1993; Christian et al. 2002; Fisher et al. 1989; Luna et al. 2006; Torgler and Schaltegger 2005). These economicsbased studies implicitly assume that a taxpayer's motivation for making a tax amnesty disclosure arises as a result of a cost-benefit analysis. However, there is evidence that taxpayers are also motivated by non-economic reasons when making compliance decisions (e.g., Alm and Torgler 2011; Baldry 1986). Tax ethics researchers have concluded that tax ethics requires a multifaceted policy approach that includes cognitive and affective aspects of human behaviour (Coricelli et al. 2010; Maciejovsky et al. 2012). Accordingly, we use three guilt cognitions to explain tax amnesty behaviour.

Several tax studies consider guilt to be an important motivating factor in influencing tax decision-making. Grasmick and Scott (1982) found that of sanctions, social stigma, and guilt feelings, the deterrence mechanism with the greatest inhibitory effect on non-compliance was guilt feelings. Coricelli et al. (2010) find that there is an emotional cost to tax evasion, such that emotional arousal increases when tax evasion is initially detected, and is even stronger if the evader's cheating is made public. Also, Cho et al. (1996) suggest that the 'psychic costs' of tax evasion may be high enough to prevent any economic gains from tax evasion. However, to the best of our knowledge, no studies have examined the direct relationship between guilt cognitions and tax amnesty disclosures. 
The tax compliance literature lacks a theoretically rigorous model of guilt (Alm 2012). We therefore adopt insights from Kubany and Watson's (2003) multidimensional model since it is, to the best of our knowledge, the most comprehensive model of guilt. Kubany and Watson (2003) state that theoretical discussions of guilt tend to be brief, that there is no consensus about the determinants of guilt, and that there has been little effort to test competing conceptualizations of guilt. Accordingly, their model was developed to address these shortcomings. Although their model has not yet received empirical support, it appears relevant for this study, since it was formulated to account for guilt that occurs in response to common guilt-evoking events.

Kubany and Watson (2003) propose that guilt is a function of five factors: distress, responsibility for a decision, justification for a decision, foreseeability of the consequences arising from a decision, and personal values. In order for guilt to be perceived, there must be distress (unpleasant feelings associated with a negative outcome), as well as cognitions that the individual played a role in the negative outcome. Thus, guilt would be highest when an individual is distressed, takes full responsibility for causing the negative outcome, cannot justify the decision, foresaw the negative consequences arising from the decision, and the act violated the individual's personal values. Kubany and Watson (2003) suggest that any social circumstance that produces distress and heightens the likelihood that an individual will perceive himself or herself as playing a role in a negative event is expected to heighten the probability of guilt. When extended to the tax context, it follows that a taxpayer who has committed tax evasion will be distressed, and is likely to experience guilt if she takes full responsibility for her choice to evade, cannot justify the decision to evade, foresaw that the evasion would be detected, and the act violated her personal values. 
This study focuses on three guilt cognitions: responsibility for a decision, justification for a decision, and foreseeability of the possible consequences ${ }^{2}$. These three cognitions are likely to be relevant for taxpayer decision-making, since a taxpayer assumes a degree of responsibility for his or her tax reporting decision, has to be able to justify a tax reporting decision, and understands the possible negative consequences of an inaccurate tax reporting decision. There is also empirical evidence about the influence of each of responsibility, justification, and foreseeability on individual behaviour. For example, Curtis (2006) found a significant and positive main effect of personal responsibility on personal reporting intentions in a public accounting context. There is also a broad psychology literature showing that personal responsibility assumed for one's behaviour affects behaviour outcomes for a variety of situations (Mulilis et al. 2001). Shalvi et al. (2011) found that the degree of lying depends on the extent to which self-justifications are available: the greater the degree of justification, the greater the incidence of lying. Crawford et al. (1990) found that higher foreseeability was significantly associated with rape victim blaming, while Lagnado and Channon (2008) found a strong influence of foreseeability on blameworthy behaviour, such that actions that were foreseeable were more likely to be blameworthy.

Although researchers have found that each of responsibility, justification, and foreseeability influence behaviour, we are unaware of any empirical studies that have

\footnotetext{
${ }^{2}$ The other two aspects of guilt, in Kubany and Watson's (2003) model, are distress and personal values. Distress is an affective state involving feelings of unhappiness, depression and anxiety (Hardy et al. 2003) that can result in emotional exhaustion (Tepper et al. 2007). It is impossible for us to manipulate these emotional feelings in an experimental context, and so we controlled for distress in our experiment. The other guilt cognition is personal values. "A personal value system is viewed as a relatively permanent perceptual framework which shapes and influences the general nature of an individual's behavior. Values are similar to attitudes but are ingrained, permanent, and stable in nature." (England 1967, p.54). In a tax situation, personal values refer to beliefs about the ethics of tax evasion. Since there is variation in personal values (England 1967), it is not possible for us to operationalize these in our experiment, and so we also controlled for attitudes concerning the ethicality of tax evasion.
} 
investigated the joint effect of these three factors. Kubany and Watson's (2003) model of guilt predicts that these three guilt cognitions will jointly influence behaviour. Consequently, we predict an interaction effect of responsibility, justification, and foreseeability on tax amnesty disclosure decisions.

Hypothesis: Responsibility, justification, and foreseeability will jointly influence the likelihood of making a tax amnesty disclosure.

We do not specify the form of an interaction because Kubany and Watson's (2003) model does not predict the form of an interaction. ${ }^{3}$

\section{Methodology}

\section{Design}

We employ a 2 (responsibility for the decision: high, low) $\times 2$ (justification of the decision: high, low) x 2 (foreseeability of the consequences: high, low) fully crossed betweensubjects design.

\section{Participants}

Participants were Canadian taxpayers recruited from a consumer research firm that has a database of 200,000 Canadians. To be representative of a typical taxpayer population, we requested our participants be randomly selected using two parameters: gender and age. We restricted our sample participants to taxpayers between the ages of 25 to 80 , evenly distributed across age groups, with a 50/50 gender split. We required a minimum of 50 responses for each of

\footnotetext{
${ }^{3}$ We do not predict main effects because main effects should not be tested if there is a significant interaction effect (Maxwell \& Delaney (2004, p.331).
} 
the 8 conditions. All participants were from the same province. A total of 10,166 invitations were sent out, and after we received 254 responses we terminated the data collection. Fifteen of these responses contained missing data, leaving us with 239 responses. Demographic data is reported in Table 1.

[Insert Table 1 about here]

\section{Experimental Procedures}

Potential participants received an email invitation from the consumer research firm to participate in a questionnaire about income taxes. Individuals willing to participate in the experiment clicked on a web link, and were automatically directed to one of the experimental conditions. Participants had a unique user ID and password provided by the firm, which ensured that they could not respond to the survey more than once. Participants were incented using a point system specific to the firm. After random assignment to experimental conditions, participants in all conditions read an experimental scenario.

The scenario described a taxpayer named Mary who received a large inheritance, transferred the proceeds to a bank account in the Cayman Islands, but did not report the subsequent taxable investment income to the tax authority. We chose an international context to enhance realism, given the recent efforts of various governments to publicly address the problem of international tax evasion (Canada 2013; Chan et al. 2011). In Canada, as in other countries, taxpayers must report their worldwide income from all sources on their annual tax return. Consequently, the taxpayer in the scenario was required by law to report her offshore income. 
In the experiment, participants read background information about the Voluntary Disclosure Program offered by the Canada Revenue Agency (CRA). They learned that under this program, a taxpayer could correct a previous error, would still have to pay income tax on the previously unreported amount, plus interest, but would neither be penalized nor prosecuted. Participants were also informed that if the CRA discovered the error before the taxpayer made a tax amnesty disclosure, the consequences would be more severe: in addition to the income taxes and interest owed, there would be penalties, and the taxpayer could be jailed if the error was intentional. Participants then read the second part of the scenario, which included the three manipulations about responsibility for tax reporting, justification for not reporting the taxable income, and foreseeability of the possible negative consequences for not reporting the taxable income. They also answered follow-up questions, which included manipulation checks and demographic questions. The wording for all experimental manipulations is contained in the Appendix.

\section{Dependent Variable}

Our primary dependent measure was whether participants thought that Mary would make an amnesty disclosure (yes or no) about the previously unreported taxable investment income that she earned in the Cayman Islands. We used a binary dependent variable, consistent with past tax amnesty studies (Alm et al. 1990, Christian et al. 2002; Marceau and Mongrain 2000).

\section{Independent Variables}

There are three independent variables: responsibility for the decision, justification for the decision, and foreseeability of consequences. We operationalized responsibility according to 
whether or not Mary was solely responsible for the tax reporting decision, consistent with Zhang et al. (2009). In the high responsibility condition, Mary assumed sole responsibility for her initial tax reporting decision, whereas in the low responsibility condition, a tax advisor provided insights that diffused the responsibility. We operationalized justification according to whether Mary had a viable or a poor reason for not reporting the investment income, following Haines and Jost (2000). In the high justification condition, Mary used the cash that would have been paid in taxes to purchase cancer medication for her young daughter, whereas in the low justification condition, she made renovations to her house. We operationalized foreseeability as the degree to which Mary anticipated negative consequences from her decision (Griffin et al., 1996) based on her expectation of being caught by the CRA. In the high foreseeability condition, Mary learned that the CRA was working on an information sharing agreement with the Cayman Islands bank so that the CRA would obtain the names of all Canadian investors. In the low foreseeability condition, Mary learned that it would be virtually impossible for the CRA to obtain information about Canadians who had investments in the Cayman Islands.

\section{Control Variables}

Kubany and Watson's (2003) model involves five guilt factors: responsibility, justification, foreseeability, distress, and personal values. Responsibility, justification, and foreseeability were the independent variables in our model. As mentioned (in footnote 2) it was impossible for us to manipulate feelings of distress about tax evasion as well as to manipulate individual attitudes concerning the ethicality of tax evasion. Consequently, we controlled for both distress and personal values. We measured distress by asking participants to rate their level of agreement on a 7-point scale with the statement, Mary would feel distressed by what she did, 
consistent with Masten et al. (2011). We measured personal values by asking participants to rate their level of agreement on a 7-point scale with two statements about the morality of tax evasion, It is morally wrong to engage in tax evasion behaviour, and, My close friends believe it is unethical to engage in tax evasion behaviour. We used an average score of these items in our analysis (Cronbach alpha $=0.76)$. These two statements were adopted from Bobek et al. (2013).

We controlled for demographic variables (age, gender, tax preparer, income and education) consistent with Bobek et al. (2013) and Chung and Trivedi (2003). Finally, we asked whether or not the participant had ever been audited by the CRA, since a prior audit experience may have influenced the responses to the questions.

\section{Results}

\section{Manipulation Effectiveness}

We performed manipulation checks for responsibility, justification, and foreseeability of consequences. Our manipulation check for responsibility asked participants to rate their agreement with the statement, Mary has only herself to blame for not reporting the investment income. Our manipulation check for justification asked participants to rate their agreement with the statement, Mary has a good reason for not reporting the investment income. Our manipulation check for foreseeability of consequences asked participants to rate their agreement with the statement, The CRA will find out that Mary had underreported her investment income. All statements were measured with 7-point Likert scales, with 1 being 'strongly agree' and 7 being 'strongly disagree'. Responsibility $(\mathrm{F}=6.45, \mathrm{p}=0.01)$, justification $(\mathrm{F}=14.80, \mathrm{p}<0.01)$, and 
foreseeability $(\mathrm{F}=23.90, \mathrm{p}<0.01)$ manipulation checks were supported, and all in the expected direction.

\section{Test of the Hypothesis}

We hypothesized a three-way interaction effect of responsibility, justification and foreseeability on the likelihood of making a tax amnesty disclosure. To test our hypothesis, we used binary logistic regression analysis, since our dependent variable and independent variables are dichotomous (Jaccard 2001). We used dummy variables of ' 0 ' for the 'low' conditions and ' 1 ' for the 'high' conditions. We also used dummy variables of ' 0 ' if the participant said that Mary would not make an amnesty disclosure and ' 1 ' if the participant said that Mary would make an amnesty disclosure.

We entered all independent variables and control variables simultaneously. Following Field (2009), we first checked for multicollinearity using the tolerance and VIF statistics, and found no evidence of multicollinearity in the logistic regression model. The model fit statistics indicated an acceptable fit to the data, given the Hosmer-Lemeshow statistic $\left(\chi^{2}=5.66, p=0.69\right)$ was not significant (Field 2009). We also inspected the standardized residuals and deviance statistics (Cook's distance). No standardized residuals exceeded 3, and no Cook's distance exceeded 1, which also indicated an acceptable model fit (Field 2009). Regression results are reported in Table 2.

[Insert Table 2 about here]

Support for our hypothesis would be evidenced by a significant and positive interaction term between responsibility, justification, and foreseeability. As per Table 2, this interaction term 
was positive and significant $(\mathrm{p}=0.03)$. Consequently, our hypothesis was supported.

Responsibility, justification, and foreseeability jointly influence the likelihood of making a tax amnesty disclosure.

The independent variables - responsibility, justification, and foreseeability - were, respectively, not significant $(\mathrm{p}=.28)$, marginally significant $(\mathrm{p}=.07)$, and statistically significant $(p=.03)$ in the full model. However, we are unable to interpret these results because there was a statistically significant three-way interaction among these variables. According to Maxwell and Delaney (2004, p.376), "When a significant three-way interaction is obtained, it is generally preferable to consider effects within such individual levels of other factors instead of interpreting the main effects themselves." Therefore, we only analyzed the predicted interaction.

\section{Second Stage Analysis}

To interpret the significant three-way interaction, we followed the approach suggested by Jaccard (2001). First, we specified a focal independent variable, which was foreseeability, since it was the only statistically significant main effect $(p=.03$ per Table 2$)$. We then identify a firstorder moderator variable. The significant two-way interaction was between foreseeability and justification ( $\mathrm{p}=0.02$ per Table 2 ). Therefore, justification became the first-order moderator variable. The remaining independent variable (responsibility) became the second-order moderator variable. Using this classification of focal independent variable, first-order moderator variable, and second-order moderator variable, we graphed the interaction. The graph of the interaction is presented in Figure 1. We also tabulated results from a statistical analysis in Table 3 , in which we show the probabilities of making an amnesty disclosure, as well as the odds ratios of making a tax amnesty disclosure, across experimental conditions. 
[Insert Figure 1 about here]

[Insert Table 3 about here]

Results from the graph indicated that, in general, participants thought that a taxpayer was more likely to make a tax amnesty disclosure if the taxpayer foresaw that she would be caught by the tax authority. This trend was consistent across all experimental conditions, except for the high justification, low responsibility condition, in which the likelihood of making a voluntary disclosure actually decreased as the experimental conditions moved from low foreseeability to high foreseeability.

\section{Sensitivity Analysis}

Of the other two guilt variables in Kubany and Watson's (2003) model, distress was statistically significant $(\mathrm{p}<0.01)$, whereas personal values was marginally significant $(\mathrm{p}=0.07)$. To check the robustness of the three-way interaction, we first ran the regression with distress and personal values as the only control variables, since Kubany and Watson's (2003) model has just these five constructs. The three-way interaction term was again significant $(\mathrm{p}=0.03)$. Additionally, we then ran the regression with no control variables and the three-way interaction term remained significant $(\mathrm{p}=0.03)$. These non-tabulated sensitivity analyses confirmed the robustness of our results.

\section{Discussion of Results}

Participants were most likely to say that Mary would make an amnesty disclosure when she foresaw that the tax authority was likely to detect her tax evasion, when she assumed sole 
responsibility for her tax reporting decision, and when she had a good justification for her erroneous tax reporting decision. Per Table 3 , the odds ratio in this condition was 1.81 , which meant that for every 100 individuals who said that Mary would not make an amnesty disclosure, 181 said that Mary would make an amnesty disclosure. Results also showed that participants were least likely to say that Mary would make an amnesty disclosure when she did not foresee that the tax authority was likely to detect her tax evasion, when she did not assume full responsibility for her tax reporting decision, and when she had a poor justification for her erroneous tax reporting decision. The odds ratio in this condition was 0.161 , which meant that for every 100 individuals who said that Mary would not make an amnesty disclosure, only 16 said she would make a disclosure. Thus, the highest probability of amnesty disclosures occurred when each of the three guilt cognitions were high, and the lowest probability of amnesty disclosures occurred when each of the three guilt cognitions were low.

The trend from the graph was upward sloping in three of the four conditions of justification and responsibility (the high justification and low responsibility condition being the exception). Thus, as Mary moved from low to high foreseeability, even if she could not justify her tax evasion, and irrespective of her perceived responsibilities, participants said that the probability of her making an amnesty disclosure increased. Also, as Mary moved from low to high foreseeability, even if she could justify her tax evasion and took sole responsibility for her tax reporting decisions, participants said that the likelihood of her making an amnesty disclosure increased. However, when Mary moved from low to high foreseeability, and she could justify her tax evasion but did not accept full responsibility for her erroneous tax reporting, participants said that the probability of her making an amnesty disclosure decreased. Specifically, the odds ratio in the low foreseeability, high justification and low responsibility condition was 0.522 , 
whereas the odds ratio in the high foreseeability, high justification and low responsibility condition was 0.291 . Thus, participants were about half as likely to say that Mary would make an amnesty disclosure if she thought that her tax evasion would be detected.

\section{Implications}

Tax ethics researchers have not examined the impact of affective aspects of human behaviour, such as guilt, on tax amnesties, despite suggestions that guilt feelings can motivate taxpayer decision-making (Alm 2012, Cho et al. 1996, Grasmick and Scott 1982). Our study extends prior tax compliance research by predicting and finding a positive relation between guilt cognitions and taxpayers' amnesty disclosure decisions. We find an interactive impact of three guilt cognitions - responsibility for a decision, justification for a decision, and foreseeability of consequences - on restorative behaviour following a transgression. We also provide partial empirical support for Kubany and Watson's (2003) multidimensional model of guilt, since we find that three guilt cognitions act in tandem to influence behaviour. Finally, our research makes a contribution to the restorative justice literature.

Retributive justice tends to focus on punishment; restorative justice involves a bilateral process that reaffirms shared values (Wenzel et al. 2008). "Restorative justice involves repairing and restoring relationships damaged through unethical behavior, focusing in particular on actions taken by offenders to make amends." (Goodstein and Butterfield 2010, p. 453-454). Specifically, restorative justice involves "having offenders (a) accept responsibility and accountability, (b) engage in respectful dialogue with those affected by the wrongdoing, (c) feel remorse, and (d) offer apologies and/or restitution." (Goodstein and Butterield 2010, p. 456). In a tax amnesty program, the offending taxpayer feels remorse and guilt, accepts responsibility for engaging in 
the tax evasion, and makes restitution by paying the taxes on the previously unreported taxable income. Thus, tax amnesty programs help to re-establish a taxpayer-tax authority relationship that has been damaged through tax evasion. Even though we make no comment on whether or not the dialogue with the tax authority is respectful, it appears, nevertheless, that guilt cognitions may be effective at encouraging restorative justice.

Tax evasion is both an ethical issue (Baldry 1986) as well as an emotional one (Mason and Calvin 1984) from the viewpoint of both tax evaders and compliant taxpayers. From the compliant taxpayers' perspective, there is a perceived social norm concerning fairness such that taxpayers have a strong negative emotional response to tax evaders; they think that they should be punished (Lévy-Garboua et al. 2009). For the evader, Coricelli et al. (2010) find that emotional arousal increases, from a feeling of guilt when the evasion is detected by the tax authority, to a feeling of shame when the tax evasion is made public. There are a variety of reasons why people engage in tax evasion: perceptions that tax rates are too high; beliefs that the government wastes tax dollars; and participation in the underground economy (Molero and Pujol 2012). While we expect cheating and amnesty disclosure decisions to have similar motivations, we find that not making an amnesty disclosure is related to a strong justification for cheating in the first place, which is contrary to what we expected. Instead the participants thought that the likelihood of making a tax amnesty disclosure would increase when the taxpayer could justify the evasion. This suggests that justification may interact differently than expected when combined with responsibility and foreseeability, perhaps because of the emotional nature of justification. We leave it to future researchers to examine in more detail the impact of an emotional justification on tax evasion. 
Economics-based research suggests that tax amnesty programs can improve tax revenue collection, but that these programs will not influence the majority of tax evaders to come forward (Alm et al. 1990; Alm and Beck 1993; Alm 2012; Christian et al. 2002; Fisher et al. 1989; Luna et al. 2006; Torgler and Schaltegger 2005). Therefore, it is important for tax amnesty policy makers to consider additional ways to motivate delinquent taxpayers to self-correct. Some researchers have suggested that appeals to emotions may be more effective at securing compliance than simply using sanctions (Coricelli et al. 2010, Mason and Calvin 1984). Our results support this line of thought and that tax authorities consider making appeals to guilt.

Tax authorities could encourage self-correction by promoting a message like, "get to us before we get to you", which was the slogan from Michigan's 1986 Tax Amnesty Program. Tax authorities could consider ways to promote this message through marketing initiatives such as advertising campaigns, perhaps using the tax authority's online tax return submission portal, or television. Previous tax research suggests that public service messages delivered via television are effective at influencing taxpayers' attitudes towards compliance (Roberts 1994). Given that a fundamental problem in business is how to motivate people to do what they already know is right (Hamilton and Strutton 1994), our findings suggest that an amnesty may be a practical solution to this broad problem, especially if appeals to guilt are part of the amnesty. Guilt appeals may motivate people to 'do the right thing'. The combination of guilt appeals and a tax amnesty program should have the potential to be an administratively cost effective means of increasing tax revenues.

The results may have implications for professionals who have opportunities to provide tax-related advice. In our experiment, the probability of making a tax amnesty disclosure decreased when Mary did not take personal responsibility for the initial decision to evade taxes 
because she learnt about the benefits of evasion from her tax advisor. Although the tax advisor never suggested that Mary engage in evasion, the advisor did mention that she would not receive any tax forms, and could save a lot of money in taxes. Thus, just by providing informal information or inferences, without providing actual advice, a tax advisor may diffuse the personal responsibility of the client for tax reporting purposes. A broader implication is that any professionals who are engaged in providing counsel and advice should refrain from mentioning the existence of unethical options, since the mere mention of a questionable alternative, even if not formally construed as advice, may be enough to diffuse the client's personal responsibility. Professional standards could consider expanding guidance on this topic, and accounting firms and universities could emphasize the importance of personal responsibility during training.

There are several limitations to our study. First, the results from this research are specifically tested on Canadian taxpayers. Since we randomly assigned participants to conditions, we have no reason to believe that the results would not generalize to taxpayers from other countries, but we nonetheless suggest caution. Second, due to the sensitive nature of tax evasion, it is possible that participants' responses were biased. While we may observe different overall levels of individuals making amnesty disclosures in our experimental conditions, because of random assignment, we would expect to observe directionally similar effects outside of experimental conditions. In addition, we attempted to mitigate this concern by assuring participants of anonymity and by asking them what they thought the hypothetical taxpayer in the scenario would do, rather than what the participants themselves would do in similar circumstances. Finally, unlike many studies that use students, our participants were taxpayers, which increases the reliability of our findings.

\section{Conclusion}


The purpose of our study is to examine the impact of guilt on tax amnesty disclosure decisions. We find that the likelihood of a taxpayer making an amnesty disclosure is greatest when the individual assumes personal responsibility for the transgression, can justify the transgression, and can foresee the negative consequences arising from the transgression. Conversely, the likelihood of a taxpayer making an amnesty disclosure is lowest when the individual can diffuse personal responsibility for the transgression, cannot justify the transgression, and does not anticipate being caught.

Tax amnesties are administratively low cost programs that generate only modest amounts of tax revenue. Our results indicate that these programs may be improved, and more taxes collected, if they are linked to guilt appeals. Guilt is a powerful emotion that may encourage delinquent taxpayers to self-correct. An emotional appeal for taxpayers to amend their previously erroneous tax returns and pay the taxes that should have been remitted may increase tax revenue.

We encourage further research on guilt cognitions and their influence on restorative behaviour in other tax and non-tax contexts. Future research could extend this study in other national tax contexts or could consider other aspects of tax amnesties. For example, does varying the incentives to make amnesty disclosures affect the incidence of voluntary disclosures? Researchers could also consider other moderating influences on guilt cognitions, such as personality traits. 


\section{REFERENCES}

Alm, J. (2012). Measuring, explaining, and controlling tax evasion: lessons from theory, experiments, and field studies. International Tax and Public Finance, 19(1), 54-77.

Alm, J. and Torgler, B. (2011). Do ethics matter? Tax compliance and morality. Journal of Business Ethics, 101(4), 635-651.

Alm, J., and Beck, W. (1993). Tax amnesties and compliance in the long run: A time series analysis. National Tax Journal, 46(1), 53-60.

Alm, J., McKee, M., and Beck, W. (1990). Amazing grace: Tax amnesties and compliance. National Tax Journal, 43(1), 23-37.

Baer, K., and Le Borgne, E. (2008). Tax Amnesties: Theory, Trends, and Some Alternatives. Washington, DC: International Monetary Fund.

Baldry, J. (1986). Tax evasion is not a gamble. Economics Letters, 22 (1): 333-335.

Bobek, D., Hageman, A. and Kelliher, C. (2013). Analyzing the role of social norms in tax compliance behavior. Journal of Business Ethics, 115(3): 451-468.

Canadians for Tax Fairness (2014). Tackle Tax Havens. Online:

http://www.taxfairness.ca/action/tackle-tax-havens

Canada (2013). Economic Action Plan 2013. Online: http://actionplan.gc.ca/en/page/economicaction-plan-2013

Chan, S., Cheung, D., and Andrew, B. (2011). Taxpayers' rights under the liberalization of tax information provisions in Hong Kong. International Tax Journal, 37(4): 13-22, 59-60.

Christian, C., Gupta, S., and Young, J. (2002). Evidence on subsequent filing from the state of Michigan's income tax amnesty. National Tax Journal, 55(4), 703-721.

Cho, J., Linn, S., and Nakibullah, A. (1996). Tax evasion with psychic costs and penalty renegotiation. Southern Economic Journal, 63(1): 172-190.

Chung, J. and Trivedi, V. (2003). The effect of friendly persuasion and gender on taxpayers' compliance behavior. Journal of Business Ethics 47(2): 133-145.

Coricelli, G., Joffily, M., Montmarquette, C., and Villeval, M. (2010). Cheating, emotions, and rationality: An experiment on tax evasion. Experimental Economics 13 (2): 226-247.

Crawford, J., McCaul, K., Veltum, L. and Bouechko, V. (1990). Understanding attributions of victim blame for rape: sex, violence, and foreseeability. Journal of Applied Social Psychology, 20(1): 1-26. 
Curtis, M. (2006). Are audit-related ethical decisions dependent upon mood? Journal of Business Ethics, 68(2):191-209.

Eisenberg, N. (2000). Emotion, regulation, and moral development. Annual Review of Psychology, 51(1): 665-697.

England, G. (1967). Personal value systems of American managers. Academy of Management Journal, 10 (1): 53-68.

Ferguson, T. and Stegge, H. (1998). Measuring guilt in children: A rose by any other name still has thorns. In Bybee, J. (ed.), Guilt in children (pp 19-74). New York: Academic Press.

Field, A. (2009). Discovering Statistics Using SPSS, $3^{\text {rd }}$ Ed. Thousand Oaks, CA: Sage Publications.

Fisher, R., Goddeeris, J., and Young, J. (1989). Participation in tax amnesties: The individual income tax. National Tax Journal, 42(1), 15-27.

Ghorbani, M., Liao, Y., $\square$ ayköylü, S., and Chand, M. (2013). Guilt, shame, and reparative behavior: The effect of psychological proximity. Journal of Business Ethics, 114(2): 311-323.

Goodstein, J., and Butterfield, K. (2010). Extending the horizon of business ethics: Restorative justice and the aftermath of unethical behavior. Business Ethics Quarterly, 20 (3): 433-480.

Grasmick, H. and Scott, W. (1982). Tax evasion and mechanisms of social control: A comparison with grand and petty theft. Journal of Economic Psychology, 2(3): 213-230.

Griffin, M., Babin, B., and Attaway, J. (1996). Anticipation of injurious consumption outcomes and its impact on consumer attributions of blame. Journal of the Academy of Marketing Science, 24(4): 314-327.

Haines, E., and Jost, J. (2000). Placating the powerless: Effects of legitimate and illegitimate explanation on affect, memory, and stereotyping. Social Justice Research, 13(3): 219-236.

Hamilton, J. and Strutton, D. (1994). Two practical guidelines for resolving truth-telling problems. Journal of Business Ethics, 13(11): 899-912.

Hardy, G., Woods, D., and Wall, T. (2003). The impact of psychological distress on absence from work. Journal of Applied Psychology, 88(2): 306-314.

Ilies, R., Peng, A., Savani, K., and Dimotakis, N. (2013). Guilty and helpful: An emotion-based reparatory model of voluntary work behavior. Journal of Applied Psychology, 98(6): 1051-1059.

Internal Revenue Service (2011). Tax Gap "Map" Tax Year 2006. Online: http://www.irs.gov/pub/newsroom/tax_gap_map_2006.pdf 
Jaccard, J. (2001). Interaction effects in logistic regression. Thousand Oaks, CA: Sage Publications.

Kubany, E. and Watson, S. (2003). Guilt: elaboration of a multidimensional model. The Psychological Record, 53(1): 51-90.

Lagnado, D., and Channon, S. (2008). Judgments of cause and blame: The effects of intentionality and foreseeability. Cognition, 108(3): 754-770.

Lévy-Garboua, L., Masclet, D., and Montmarquette, C. (2009). A behavioral Laffer curve: Emergence of a social norm of fairness in a real effort experiment. Journal of Economic Psychology 30: 147-161.

Luna, L., Brown, M., Mantzke, R., Tower, R. and L. Wright (2006). State tax amnesties: forgiveness is divine - and possible profitable. State Tax Notes, August 21, 497-511.

Maciejovsky, B., Schwarzenberger, H. and Kirchler, E. (2012). Rationality vs. emotions: The case of tax ethics and compliance. Journal of Business Ethics, 109(3), 339-350.

Marceau, N., and Mongrain, S. (2000). Amnesties and Co-operation. International Tax and Public Finance, 7(3): 259-273.

Mason, R., and Calvin, L. (1984). Public confidence and admitted tax evasion: Abstract. National Tax Journal, 37 (4): 489-498.

Masten, C., Telzer, E., and Eisenberger, N. (2011). An fMRI investigation of attributing negative social treatment to racial discrimination. Journal of Cognitive Neuroscience, 23(5): 1042-1051.

Maxwell, S., and Delaney, H. (2004). Designing Experiments and Analyzing Data: A Model Comparison Perspective ( $2^{\text {nd }}$ ed). Lawrence Erlbaum Associates, Mahwah, NJ.

Molero, J., and Pujol, F. (2012). Walking inside the potential tax evader's mind: Tax morale does matter. Journal of Business Ethics 105: 151-162.

Mulilis, J-P., Duval, T., and Rombach, D. (2001). Personal responsibility for tornado preparedness: Commitment or choice? Journal of Applied Social Psychology, 31(8): 1659-1688.

Shalvi, S., Dana, J., Handgraaf, M., and De Dreu, C. (2011). Justified ethicality: Observing desired counterfactuals modifies ethical perceptions and behavior. Organizational Behavior and Human Decision Processes, 115(2): 181-190.

Roberts, M. (1994). An experimental approach to changing taxpayers' attitudes towards fairness and compliance via television. The Journal of the American Taxation Association, 16(1), 67-86.

Slemrod, J. (2007). Cheating ourselves: The economics of tax evasion. Journal of Economic Perspectives, 21(1), 25-48. 
Smith, R., Webster, J., Parrott, W. and Eyre, H. (2002). The role of public exposure in moral and nonmoral shame and guilt. Journal of Personality and Social Psychology, 83(1): 138-159.

Steenhaut, S., and Van Kenhove, P. (2006). The mediating role of anticipated guilt in consumers' ethical decision-making. Journal of Business Ethics, 69(3): 269-288.

Tangney, J., Stuewig, J., and Mashek, D. (2007). Moral emotions and moral behavior. Annual Review of Psychology, 58(1): 345-372.

Tepper, B., Moss, S., Lockhart, D., and Carr, J. (2007). Abusive supervision, upward maintenance communication, and subordinates' psychological distress. Academy of Management Journal, 50 (5): 1169-1180.

Torgler, B., and Schaltegger, C. (2005). Tax amnesties and political participation. Public Finance Review, 33(3), 403-431.

Weinreb, A. (2009). Tax amnesty programs and voluntary compliance initiatives: A way to mitigate declining state revenues. The Tax Adviser, 40(6), 396-400.

Wenzel, M., Okimoto, T., Feather, N., and Platow, M. (2008). Retributive and restorative justice. Law and Human Behavior, 32(5): 375-389.

Zhang, H-J., Zhou, L-M., and Luo, Y-J. (2009). The influence of responsibility on regret intensity: An ERP study. Acta Psychological Sinica, 41(5): 454-463. 
Table 1 - Demographic profile statistics

\begin{tabular}{|c|c|}
\hline Sample size & $\mathrm{n}=239$ \\
\hline $\begin{array}{l}\text { Gender } \\
\text { male } \\
\text { female }\end{array}$ & $\begin{array}{l}\mathrm{n}=120(50.2 \%) \\
\mathrm{n}=119(49.85 \%)\end{array}$ \\
\hline Age & $\begin{array}{l}\text { mean }=46.6 \text { years } \\
\text { std dev }=13.2 \text { years }\end{array}$ \\
\hline Work experience & $\begin{array}{l}\text { mean }=22.5 \text { years } \\
\text { std dev }=14.1 \text { years }\end{array}$ \\
\hline $\begin{array}{l}\text { Previously audited } \\
\text { yes } \\
\text { no }\end{array}$ & $\begin{array}{l}n=53(22.2 \%) \\
n=186(77.8 \%)\end{array}$ \\
\hline $\begin{array}{l}\text { Income: } \\
\text { less than } \$ 25,000 \\
\text { between } \$ 25,000 \text { and } \$ 50,000 \\
\text { between } \$ 50,001 \text { and } \$ 75,000 \\
\text { between } \$ 75,001 \text { and } \$ 100,000 \\
\text { greater than } \$ 100,000 \\
\text { prefer not to answer }\end{array}$ & $\begin{array}{l}n=57(23.8 \%) \\
n=76(31.8 \%) \\
n=39(16.3 \%) \\
n=36(15.1 \%) \\
n=17(7.1 \%) \\
n=14(5.9 \%)\end{array}$ \\
\hline $\begin{array}{l}\text { Highest level of education } \\
\text { completed: } \\
\text { high school } \\
\text { community college } \\
\text { undergraduate degree } \\
\text { graduate degree } \\
\text { other }\end{array}$ & $\begin{array}{l}\mathrm{n}=59(24.7 \%) \\
\mathrm{n}=74(31.0 \%) \\
\mathrm{n}=50(20.9 \%) \\
\mathrm{n}=50(20.9 \%) \\
\mathrm{n}=6 \quad(2.5 \%)\end{array}$ \\
\hline
\end{tabular}


Table 2 - The Impact of Responsibility, Justification, and Foreseeability on Tax Amnesty Likelihood

\begin{tabular}{|c|c|c|c|c|c|c|}
\hline \multicolumn{7}{|l|}{ Logistic Regression Results } \\
\hline \multirow[t]{2}{*}{ Variable } & \multirow[t]{2}{*}{$\mathrm{B}(\mathrm{SE})$} & \multirow[t]{2}{*}{ Wald } & \multirow[t]{2}{*}{ Sig. } & \multicolumn{3}{|c|}{ 95\% C.I. for Odds Ratio } \\
\hline & & & & Lower & Odds Ratio & Upper \\
\hline Responsibility & $0.71(0.65)$ & 1.18 & 0.28 & 0.57 & 2.02 & 7.19 \\
\hline Justification & $1.18(0.66)$ & 3.19 & 0.07 & 0.89 & 3.26 & 11.89 \\
\hline Foreseeability & $1.52(0.70)$ & 4.79 & 0.03 & 1.17 & 4.59 & 17.95 \\
\hline Responsibility x Justification & $-1.33(0.90)$ & 2.16 & 0.14 & 0.05 & 0.27 & 1.56 \\
\hline Justification x Foreseeability & $-2.11(0.94)$ & 5.08 & 0.02 & 0.02 & 0.12 & 0.76 \\
\hline Responsibility x Foreseeability & $-0.42(0.95)$ & 0.20 & 0.66 & 0.10 & 0.66 & 4.22 \\
\hline $\begin{array}{l}\text { Responsibility x Justification x } \\
\text { Foreseeability }\end{array}$ & $2.88(1.32)$ & 4.74 & 0.03 & 1.33 & 17.74 & 236.35 \\
\hline Control variables & & & & & & \\
\hline Distress & $-0.51(0.10)$ & 25.12 & $<0.01$ & 0.49 & 0.60 & 0.73 \\
\hline Personal Values & $-0.21(0.11)$ & 3.33 & 0.07 & 0.65 & 0.81 & 1.02 \\
\hline Gender & $0.27(0.34)$ & 0.62 & 0.43 & 0.67 & 1.31 & 2.57 \\
\hline Audited & $0.46(0.40)$ & 1.27 & 0.26 & 0.72 & 1.58 & 3.48 \\
\hline Age & $0.03(0.02)$ & 1.72 & 0.19 & 0.98 & 1.03 & 1.08 \\
\hline Work Experience & $-0.04(0.02)$ & 2.61 & 0.11 & 0.92 & 0.96 & 1.01 \\
\hline Preparer\# & & 2.51 & 0.47 & & & \\
\hline Education\# & & 7.74 & 0.10 & & & \\
\hline Income\# & & 5.14 & 0.40 & & & \\
\hline Constant & & -1.83 & 0.29 & & & \\
\hline
\end{tabular}

\# Control variables with multiple categories are summarized due to space constraints. 
Table 3: Statistical Analysis

\begin{tabular}{|l|l|l|}
\hline \multicolumn{2}{|l|}{ Panel A: Probability of making a voluntary disclosure (by number of participants) } \\
\hline & Low Foreseeability & High Foreseeability \\
\hline $\begin{array}{l}\text { High Justification, High } \\
\text { Responsibility }\end{array}$ & $15 / 32(46.9 \%)$ & $22 / 31(71.0 \%)$ \\
\hline $\begin{array}{l}\text { High Justification, Low } \\
\text { Responsibility }\end{array}$ & $17 / 31(54.8 \%)$ & $14 / 28(50.0 \%)$ \\
\hline $\begin{array}{l}\text { Low Justification, High } \\
\text { Responsibility }\end{array}$ & $16 / 30(53.3 \%)$ & $19 / 29(65.5 \%)$ \\
\hline $\begin{array}{l}\text { Low Justification, Low } \\
\text { Responsibility }\end{array}$ & $10 / 29(34.5 \%)$ & $20 / 29(69.0 \%)$ \\
\hline $\begin{array}{l}\text { Panel B: Odds ratios of making a voluntary disclosure } \\
\text { (4) }\end{array}$ & Low Foreseeability & 1.81 \\
\hline $\begin{array}{l}\text { High Justification, High } \\
\text { Responsibility }\end{array}$ & 0.280 & 0.291 \\
\hline $\begin{array}{l}\text { High Justification, Low } \\
\text { Responsibility }\end{array}$ & 0.522 & 0.976 \\
\hline $\begin{array}{l}\text { Low Justification, High } \\
\text { Responsibility }\end{array}$ & 0.324 & 0.737 \\
\hline $\begin{array}{l}\text { Low Justification, Low } \\
\text { Responsibility }\end{array}$ & 0.161 & Foreseeability \\
\hline
\end{tabular}

\footnotetext{
${ }^{4}$ Calculations of odds ratios are as follows. For the high foreseeability conditions: high/high $=\exp (-$ $1.829+0.704+1.180+1.524-1.328-2.110-0.423+2.876) ; \mathrm{high} / \mathrm{low}=\exp (-1.829+1.180+1.524-2.110) ;$ low $/ \mathrm{high}=$ $\exp (-1.829+1.524+0.704-0.423) ;$ low $/$ low $=(-1.829+1.524)$. For the low foreseeability conditions: high/high $=$ $\exp (-1.829+0.704+1.180-1.328) ; \mathrm{high} / \mathrm{low}=\exp (-1.829+1.180) ;$ low $/$ high $=\exp (-1.829+0.704) ;$ low $/$ low $=\exp (-$ $1.829)$.
} 
Figure 1 - Three-way interaction of responsibility, justification, and foreseeability on voluntary disclosure likelihood

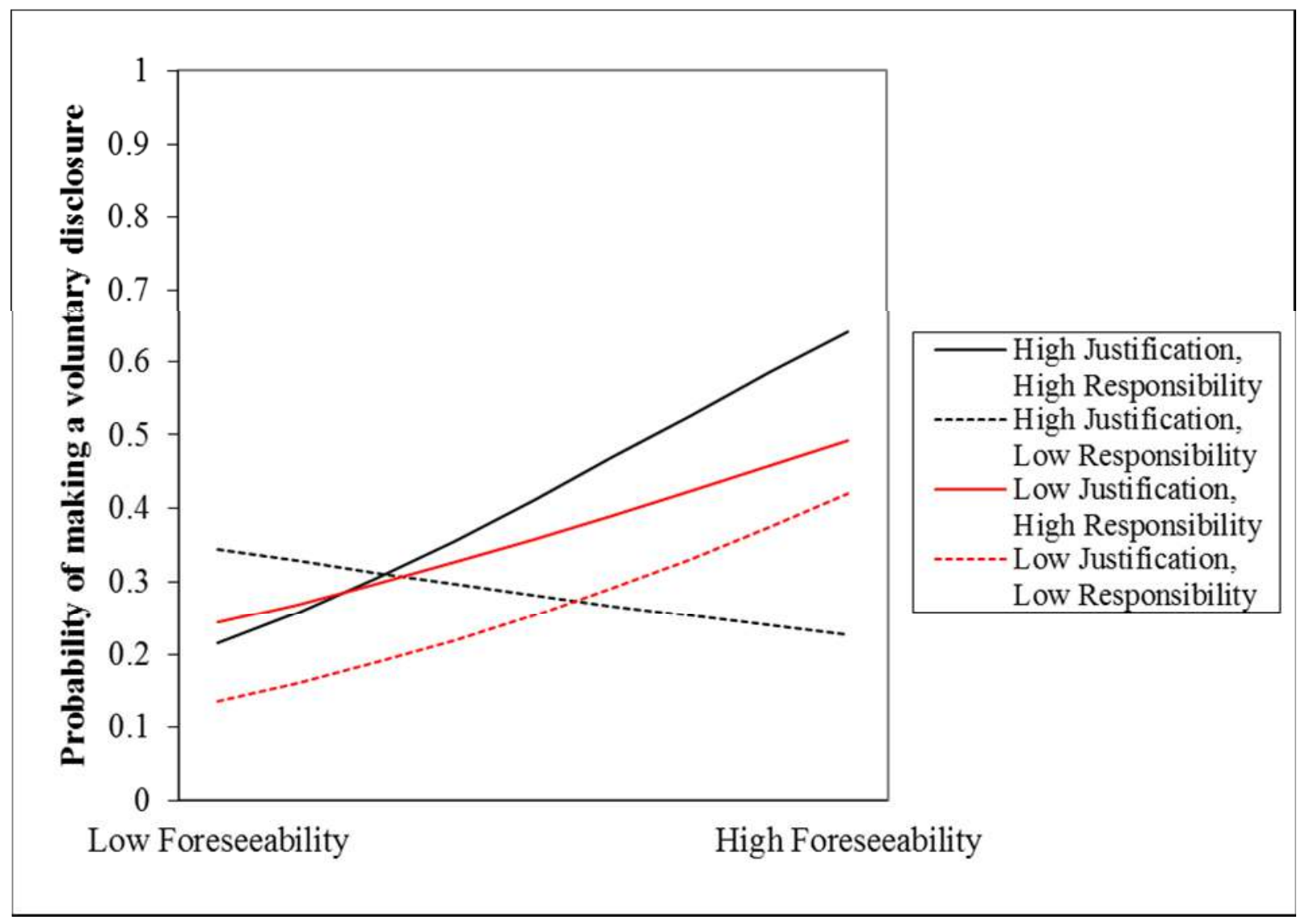




\section{Appendix}

\section{$\underline{\text { Scenario screen with manipulations }}$}

Mary is a taxpayer who lives in Ontario. Three years ago, she received a large inheritance, and transferred the proceeds to a bank account in the Cayman Islands, but transferred them back to Canada this year. The CRA does not know about this bank account and these investments. The investments generated $\$ 83,400$ annually. Her total annual income for each of the last three years was $\$ 97,500$.

\section{Responsibility manipulation}

High: Mary researched this investment opportunity, discovered that she would not receive any tax reporting forms from the Cayman Islands, and realized she could save a lot of money in taxes.

Low: Mary researched this investment opportunity, learned from her tax advisor that she would not receive any tax reporting forms from the Cayman Islands, and was told by her tax advisor that she could save a lot of money in taxes.

\section{Justification manipulation}

High: Mary has never reported any of this investment income on her Canadian tax return because she used the cash she would have paid in taxes on this investment income to pay for experimental drugs for her 4-year-old daughter, who was diagnosed with a rare and aggressive form of cancer.

Low: Mary has never reported any of this investment income on her Canadian tax return because she used the cash she would have paid in taxes for home renovations.

\section{Foreseeability manipulation}

High: Last week Mary saw a news broadcast about the importance of paying taxes. The broadcast also reported that the CRA is working on an information sharing agreement with her bank in the Cayman Islands so that the CRA could obtain the names of Canadian investors.

Low: Last week Mary saw a news broadcast about the importance of paying taxes. The broadcast also reported that it would be virtually impossible for the CRA to obtain information about Canadians who had investments in the Cayman Islands. 